\title{
Framework Development of the Social Responsibility Accounting towards Economic Units' Evaluation
}

\author{
Farooq Al Ani ${ }^{1} \&$ M. Firdouse Rahman Khan ${ }^{1}$ \\ ${ }^{1}$ Faculty of Business, Sohar University, Sultanate of Oman \\ Correspondence: Farooq Al Alani, Faculty of Business, Sohar University, Sultanate of Oman. Tel: 968-9693-7100. \\ E-mail: falani@soharuni.edu.om
}

Received: November 12, 2014

Accepted: November 20, 2014

Online Published: January 25, 2015

doi:10.5539/ijef.v7n2p253

URL: http://dx.doi.org/10.5539/ijef.v7n2p253

\begin{abstract}
Over the years, the concept of Social Responsibility Accounting (SRA) is gaining recognition and sophistication. While providing management with key performance indicators in social, environmental and economic dimensions, accountants are deemed to provide integrated reporting that is reflective of the organization's strategy and values, as well. Social Responsibility Accounting is used as a tool to evaluate the company's performance through economic units in view of Corporate Social Responsibility (CSR).

The study identifies the opportunities and challenges through the different approaches of Social Responsibility Accounting. The findings throw light on the fact that the best practice for Social Responsibility Accounting depends on the unique organizational strategies and values.

The study illustrates the challenges with which Social Responsibility Accounting needs to be extended. The study also suggests that for each organization different diagnostic and interactive approaches are used through Social Responsibility Accounting as every firm perceives a different sense of responsibility towards the society. Further, the study emphasizes the need for the legislation, industrial standards and the identification, justification and implementation of such standards. This study demonstrates a comprehensive understanding of a few of the widely accepted procedures that provide credible, quantifiable and objective measures in the performance of an organization with its focus towards CSR.
\end{abstract}

Keywords: social responsibility accounting, corporate social responsibility, corporate social performances, economic units

\section{Introduction}

Globalization has been one of the catalysts for the growing popularity of Social Responsibility Accounting (SRA). Social Responsibility Accounting is known by different names viz. Social accounting Social and Environmental Accounting, Corporate Social Reporting, Social Accounting Practices Reporting, Non-Financial Reporting and Sustainability Accounting. SRA is the process of communicating social and environmental effects of organizations' economic actions to particular interest groups within the society and to the society at large (Nkaiwatai, 2011). The concept of SRA developed in the United Kingdom during early 1970s, when the Public Interest Research Group established Social Audit Limited.

Social accounting is commonly used in the context of business, or social accounting practices although any organization, including NGOs, charities, and government agencies may engage in social accounting. However, the internal and external social accounting processes are not completely separate from the mainstream financial or management accounting processes within an organization, and both sustainability and financial employees would be involved in collecting and presenting the data (Crowther, 2000). The focus is on the elements of cost and external social welfare towards the society besides the internal goals of the firm. The imbalances between the two, the economic performances and the social welfare can only be assessed through the consistency between the strategies of the firm and the objectives of the firm and hence is the need for a mechanism to measure the social performances. Further the disclosure of the social activities towards achieving the social objectives also needs to be evaluated. In the bygone days SRA was not given utmost importance. But with globalization, firms have realized that the promotion of being socially responsible have a positive correlation with company reputation and goodwill. As profit-maximizing is one of the objectives of the firms, SRA - social responsibility 
accounting becomes a social implication for disclosing an integrated report that is reflective of the organization's strategy and values that demonstrates the firm's commitment to improve environmental performance to stakeholders.

\section{Literature Review}

Stephen (2004) claimed that the Corporate Social Responsibility (CSR) is in top-of-mind in today's corporate world. In the modern era all the firms are trying to demonstrate that they care for the social welfare and environmental impacts of their businesses. One common issue in defining CSR is that different companies label this aspect of their business strategy with different names - sustainable development, global citizenship, spiritual capitalism and value-drive business, to name a few. CSR is a concept whereby companies integrate social and environmental concerns into their business operations and in their interaction with their stakeholders on a voluntary basis (European Commission, 2001). Jones (1980) defined CSR as the notion that corporations have an obligation to constituent groups in society other than stockholders and beyond that prescribed by law and union contract. CSR is "the process by which managers within an organization think about and discuss relationships with stakeholders as well as their roles in relation to the common good, along with their behavioral disposition with respect to the fulfillment and achievement of these roles and relationships" (Basu \& Palazzo, 2008, p. 124; Heath \& Ni, 2008). Bowen (1953) referred CSR as the obligations of businessmen to pursue those policies, to make those decisions, or to follow those lines of action which are desirable in terms of the objectives and values of our society. CSR can be defined as a group of activities concerned with the measurement and analysis of social performance of business organizations and their role in maintaining the environment. The reports thus generated by the firms can be evaluated to check their social performances. This gives room to SRA to determine and measure the net social contribution of the firm periodically. Accountants have an important disposition in the debate surrounding the extent to which SRA needs to be applied and on how it can be used as a tool to evaluate economic units in view of CSR. SRA is part of the knowledge of accounting and reporting that aims to measure the social effects (social costs and benefits) arising from the business unit's activities. Mook et al. (2003), defined SRA as the social accounting that can be issued by an organization with information that allows stakeholders to the organization's performance in dealing with both positive and negative social issues.

SRA practices emphasize the conception of corporate accountability. There are four main assumptions to SRA viz.

i. Each business unit has obligations towards its surrounding communities that do not adhere to them;

ii. Goods that were previously free available, are no longer available for free as it was before;

iii. The informal social groups that have signed a social contract with the business units and the business units that are responsible for the consequences of its social obligations. The system of social accounting, social rights to this business unit, the account (social capital), is the identification and reporting;

iv. Registration and reporting of such rights and interests may not match the conventional accounting system.

In short, SRA provides a credible, quantifiable and objective evaluation of the performance of economic units in the view of SCR - social corporate responsibility, an aspect that conventional accounting falls short of. CSR is important because it is the foundation for reducing cost and gaining marketing advantage (Heath \& Ni, 2008) and is reported to be a political object in Europe and an ethical one in the US (Capron, 2006 cited in Nadia Albu, 2011). The link between CSR and organizational performance has been made in international accounting literature (Hopwood, 2009) via the concept of sustainability, by integrating economic planning with social and environmental considerations (Nadia Albu et al., 2011). CSR is not enshrined in legislation. As a result, it is neither practiced systematically by organizations nor it is able to claim either universal recognition or universal definition. To assume their social responsibilities, firms need to work in a legislative environment that defines and outlines corporate duties for the communities (Rahahleh \& Sharairi, 2008). Waddoc (2003) stated that the SRA is the subset of corporate responsibilities that deals with a company's voluntary/discretionary relationships with its societal and community stakeholder sand hence is typically undertaken with some intent to improve an important aspect of society or relationships with communities or non-governmental organizations (NGOs) (non-profits). Thus, it would be necessary to expedite the enactment of laws to oblige industrial enterprises to assume their responsibility and to issue accounting standards to this effect (Jarbou, 2006; Rahahleh \& Sharairi, 2008). It is necessary to develop the principles of disclosure and transparency to include the disclosure of the costs of environmental pollution reduction as one of the main elements of the concept of social accounting (Bamzahem, 2003). 


\subsection{Objectives of the Study}

Our theoretical framework is an opportunity towards using Corporate Social Responsibility (CSR) as an instrument in the study of Social Responsibility Accounting (SRA) and its dynamics within the organization towards the measurement and evaluation of the performances of an economic unit.

i. The study aims to identify the opportunities and challenges by the different approaches of Social Responsibility Accounting and

ii. To identify the best practice for Social Responsibility Accounting with its focus towards Social Responsibility Accounting.

\subsection{Statement of the Problem}

Social Accounting is adjudged through the various available measurement approaches and analyzed to suggest and adjudge the best amongst the alternatives, in evaluating the performances of an economic unit.

Proposition.1: There is a need for the legislation, industrial standards and implementation of such standards in Social Responsibility Accounting usage.

\section{Research Methodology}

Extensive research over the past 30 years has questioned the link between social responsibility policies and financial performance, and it is observed that there is a positive relationship between the two (Margolis \& Walsh, 2001). Nonetheless, measuring CSR and financial performance is still problematic, and it proves particularly complex to clearly define the causality between economic success and responsible behavior (Ougaard \& Nielsen, 2003). Thus, the study involves inductive research approach to determine the proposed statements. The study deals with the various different approaches available to Social Responsibility Accounting (SRA) along with the strategic motivations and implications associated with CSR i.e. the study explores the economic perspective to CSR, identifying the most common and widely used approaches to evaluating the economic units in the view of SRA. By soliciting current literature on SRA, a comprehensive analysis and interpretation aims to bring to light an underlying coherence and sense for the new perspective of reporting and evaluating economic units. By selecting the most common and widely used approaches to evaluating the economic units in the view of SRA, its analysis and interpretation is aimed to bring to light an underlying coherence and sense for the new perspective of reporting and evaluating economic units.

\subsection{The Company Level Measurement Approach (CLM)}

CLM approach has a four stage cycle viz.

i. Assessing the qualitative CSR impacts;

ii. Developing and measuring of KPIs;

iii. Assessing the monetary CSR Value Added;

iv. Evaluating the strategic relevance of each of the assessment components.

This is a systematic approach which helps to identify all the relevant CSR business impacts on a company-specific level. It also serves as a basis for rational decision-making with effect to the business CSR strategy and activities. CSR is the idea that business is accountable to various stakeholders who can be identified and have a claim, either legally mentioned or morally expected, on the business activities that affect them. CSR activities of companies are those that exceed compliance e.g., with respect to environmental or social regulations, in order to create the perception or reality that these firms are advancing a social goal (Paul \& Siegel, 2006). Because the goal of any firm is profit-maximization, recent theories on CSR suggests that the extent to which firms engage to be socially responsible is based on anticipated benefits from that engagement. Hence, we can deduce that the basic idea of corporate social responsibility is that firms and society are interwoven rather than distinct entities. Proven financial benefits of Corporate Social Responsibility can be found in the areas of human resources, reputation and branding, and operational cost savings (McElhaney, 2009). However, it can be observed from the current CSR and sustainability research that the Company Level Measurement Approach lacks in company-specific methods to evaluate individual CSR activities. It is also seen that the business approaches of investment and stakeholder evaluation are not sufficient for an application to CSR, as well. As there is no overall monetary value derived from this model, the value of one CSR activity or a decision chosen between alternative CSR actions is only possible by evaluating the strategic relevance of the business benefits a complex assessment that and requires a lot of management time and effort. It is also difficult to identify the CSR-related effects for most of the CSR benefits. 


\subsection{The Stakeholder Theory Approach (ST)}

Stakeholder Theory Approach establishes two basic principles towards CSR. Firstly, to perform well, managers need to pay attention to a wide array of stakeholders, and that managers have obligations to stakeholders which include, but extend beyond, shareholders. This theory has three premises viz.

i. Organizations have stakeholder groups that affect and are affected by them;

ii. These interactions impact on specific stakeholders and the organization;

iii. Perspectives of salient stakeholders affect the viability of strategic options.

As Jones and Wicks (1999) stresses, the stakeholder approach does not aim 'to shift the focus of firms away from marketplace success toward human decency but to come up with understandings of business in which these objectives are linked and mutually reinforcing' - what some authors call a "balanced scorecard" (Vinten, 2002). However, it is often argued that the stakeholder approach is not viable because it implies the sacrifice of profits to morally acceptable social goals. This approach is also often criticized for its relatively poor managerial practicality. The stakeholder theory itself asserts that stakeholders' interests should be taken into account, despite its vagueness in helping managers who directly deal with stakeholders.

\subsection{The Environmental Accounting and Pillars of Sustainability Approach (EAPS)}

Environmental accounting and Pillars of Sustainability approach integrates the social and economic aspects in the conventional business management processes. Steele and Powell (2002) define environmental accounting as the identification, allocation and analysis of material streams and their related money flows. Environmental accounting is an instrument of sustainability management reporting procedures that may lead to individual and organizational dynamic changes that foster organizational performance. A sustainable economy requires development of the formulation framework for the economics policy based on the ecological principles within the global warming context. Sustainability management involves managing risk, measuring and managing performance, and reporting performance internally and externally through voluntary and compulsory initiatives. Furthermore, interdisciplinary studies of the economists or ecologists are necessary to customize the new economy from the perspective of permanent progress (Brown, 2001, Cornelia et al., 2010). In sustainability management, the three pillars relate with ecological, social and economic issues (Harazin and Horvath, 2011), which in turn is connected with profit oriented business operations- the best financial and environmental positioning. The integration however poses a challenge which is examined by environmental accounting. Evaluation models for sustainability are based on an interdisciplinary approach that recognizes the necessity of a new accountability to lead toward advanced forms of decision and responsibility (Cornelia et al., 2010, p. 20). The eco-performer entity is monitoring the triple bottom line performance that equally requires the social, economic, and environmental involvement (Marcinkowska, 2007; Mathews, 2007). However, this approach may not be used as an integrated reporting tool by economic units industries that are not directly involved in extraction of ecological and environmental resources.

\subsection{The Islamic Financial Institution Approach (IFI)}

Islamic Financial Institution Approach derives from the Islamic principles of social equity and redistributive justice. Islamic Financial Institutions are meant to be socially responsible for two interrelated reasons:

i. Their status as a financial institution fulfilling a collective religious obligation (fard kifaya);

ii. Their exemplary position as a financial intermediary.

Specific responsibilities within this dual role are also framed allowing for a clear structured logic for Islamic Financial Institutions to implement policies. Islamic Corporate Social Responsibility (ICSR) derives itself from core principles in the holy Qur'an. The three major foundational principles for ICSR are

a. Vicegerency of mankind on earth;

b. Divine accountability;

c. The duty on mankind to Enjoin good and forbid evil.

The combination of these principles denotes a divine accountability for each Muslim to enjoin good and justice and forbid evil and injustice. These core principles therefore constitute the basis of individual social responsibility (Farook, 2007).

Islamic Financial Institutions existed because of the collective religious obligation of the community, its role in performing duties that is in accordance with Islamic teachings. Islamic Financial Institutions have a responsibility to comply with the form and substance of Islamic law in all aspects of their operations. Islamic 
Corporate Social responsibility is comprised of a prescription towards positive (permissible and recommended) actions and a prescription against negative (impermissible and not recommended) actions. Islamic Financial Institutions are widely accused to have generally ensured their operational status by avoiding negative actions or impermissible activities, while minimally and variedly conducting recommended activities. Disclosure is a crucial aspect of the accountability function of an Islamic Financial Institutions to its stakeholders. The other such accountability function is the Shariah Supervisory Board. However, the Shariah Supervisory Board cannot often disclose all or any social responsibility duties. Hence, it is required that Islamic Financial Institutions through IFI approach has to disclose as much information in a succinct, truthful and understandable manner to its stakeholders. From an Islamic perspective, the main objective of corporate reporting that overrides other objectives is to allow Islamic enterprises to show their compliance with Shariah (Baydoun \& Willett 1997; Farook, 2007). The implication of this objective is that IFIs have a duty to disclose all information necessary to its stakeholders about their operations, even if such information is adverse to the IFIs interest (Maali, Casson, \& Napier, 2006; Farook, 2007). However, this approach as a tool to evaluate products and services that does not comply with the Shariah laws makes it a challenge to SRA.

\section{Findings and Discussions}

As opposed to conventional accounting where a common financial reporting standard has been established to assess the value relevance of accounting data, there is still no significant coherence amongst the different approaches to Social Responsibility Accounting. This may be mainly due to the varying extents to which economic units view themselves socially responsible.

There is however a social implication to find the best practice to Social Responsibility Accounting. The comprehensive analysis of the most common literatures on the different approaches to Social Responsibility Accounting suggests how one might evaluate the performance of an economic unit. A comprehensive view of the different approaches of Social Responsibility Accounting is given in the following Table.1.

Table 1. Showing the various aspects of the different approaches of SRA

\begin{tabular}{|c|c|c|c|c|}
\hline $\begin{array}{l}\text { Approaches/ } \\
\text { Aspects }\end{array}$ & CLM & ST & EAPS & IFI \\
\hline Focus & $\begin{array}{c}\text { Business strategy } \\
\text { activities }\end{array}$ & $\begin{array}{c}\text { Morally accepted social } \\
\text { goals at the sacrifice of } \\
\text { profits }\end{array}$ & $\begin{array}{l}\text { Ecological balances through } \\
\text { Sustainability management }\end{array}$ & $\begin{array}{c}\text { Social welfare through } \\
\text { collective religious } \\
\text { obligation }\end{array}$ \\
\hline Basis of approach & $\begin{array}{l}\text { Rational decision } \\
\text { making }\end{array}$ & $\begin{array}{c}\text { Manager's obligation to } \\
\text { stakeholders }\end{array}$ & $\begin{array}{l}\text { Sustainability management } \\
\text { and environment accounting }\end{array}$ & $\begin{array}{c}\text { Islamic Principles and } \\
\text { Shariah Law }\end{array}$ \\
\hline End Result & $\begin{array}{l}\text { Strategic relevance of } \\
\text { basic benefits }\end{array}$ & $\begin{array}{c}\text { Morally accepted social } \\
\text { goals }\end{array}$ & $\begin{array}{c}\text { Reporting of ecological and } \\
\text { environment resources }\end{array}$ & $\begin{array}{l}\text { Collective obligation } \\
\text { towards the community }\end{array}$ \\
\hline Lack of approach & $\begin{array}{c}\text { No company specific } \\
\text { methods }\end{array}$ & $\begin{array}{c}\text { Implies Sacrifice of } \\
\text { projects to Social Goals }\end{array}$ & $\begin{array}{l}\text { Not applicable for industries } \\
\text { not directly involved in the } \\
\text { extraction of ecological / } \\
\text { environmental resources }\end{array}$ & $\begin{array}{c}\text { Restricted to Shariah } \\
\text { compliant accounting } \\
\text { firms only }\end{array}$ \\
\hline $\begin{array}{l}\text { Prevailing } \\
\text { Standards }\end{array}$ & $\begin{array}{c}\text { Financial standards but } \\
\text { for Corporate Social } \\
\text { Responsibilities }\end{array}$ & $\begin{array}{c}\text { No standard prevails for } \\
\text { the goals }\end{array}$ & $\begin{array}{c}\text { No environment accounting } \\
\text { standard persists }\end{array}$ & $\begin{array}{c}\text { Sariah Boards; } \\
\text { Standards laid down by } \\
\text { AAOIFI prevails for } \\
\text { Islamic financial } \\
\text { accounting only }\end{array}$ \\
\hline
\end{tabular}

Firstly, for an effective disclosure of corporate social responsibility, senior leadership and management of the firm, one must make an authenticity and firm commitment to CSR and engage in it. A clear vision of the CSR needs to be embedded within and must be reflected in the mission, vision and values of the organization. This must also be clearly communicated towards the lower-level employees. If the disclosure of corporate social responsibility is managed as a core business strategy, the approach will not only develop the CSR strategy, but will also provide a good measure - how the CSR contributes to the achievement of the firm's business objective.

Globalization has propagated positivity in the areas of transparency, ethics and communication with stakeholders. Businesses are now finding an obligation towards disclosing financial information in such a way that their initiative towards Social Corporate Responsibility is highlighted. 
Secondly, developing clear performance metrics is important in evaluating the performance of economic units in view of CSR. Full integration of CSR into the Culture, and into the existing management and performance systems shall provide a measure of CSR strategies. It is also important to align CSR strategies with the firm's core competencies so as to portray a more vivid cost-benefit relationship of its initiatives. This approach is particularly effective because the consumers, majority of which belong to the millennial generation, want a relationship more than just a business transaction. To be able to communicate better, show concern and maintain rapport with their stakeholders will have a positive impact to the profit-maximizing strategies of an economic unit.

\section{Conclusion}

In toto, Social Responsibility Accounting is currently heavily dependent on the unique organizational strategies and values of individual economic units and therefore will still be a matter of time until a generally accepted standard of practice is established for SRA - to be precise, the industrial standards for executing a legislative control over the social responsibility is missing. The same is drawn as a model - named as FRAMEWORK FACTORS MODEL (FF model) defined by Firdouse \& Farooq and is shown through the following representation diagram:

\section{FF Model showing the different approaches of SRA}

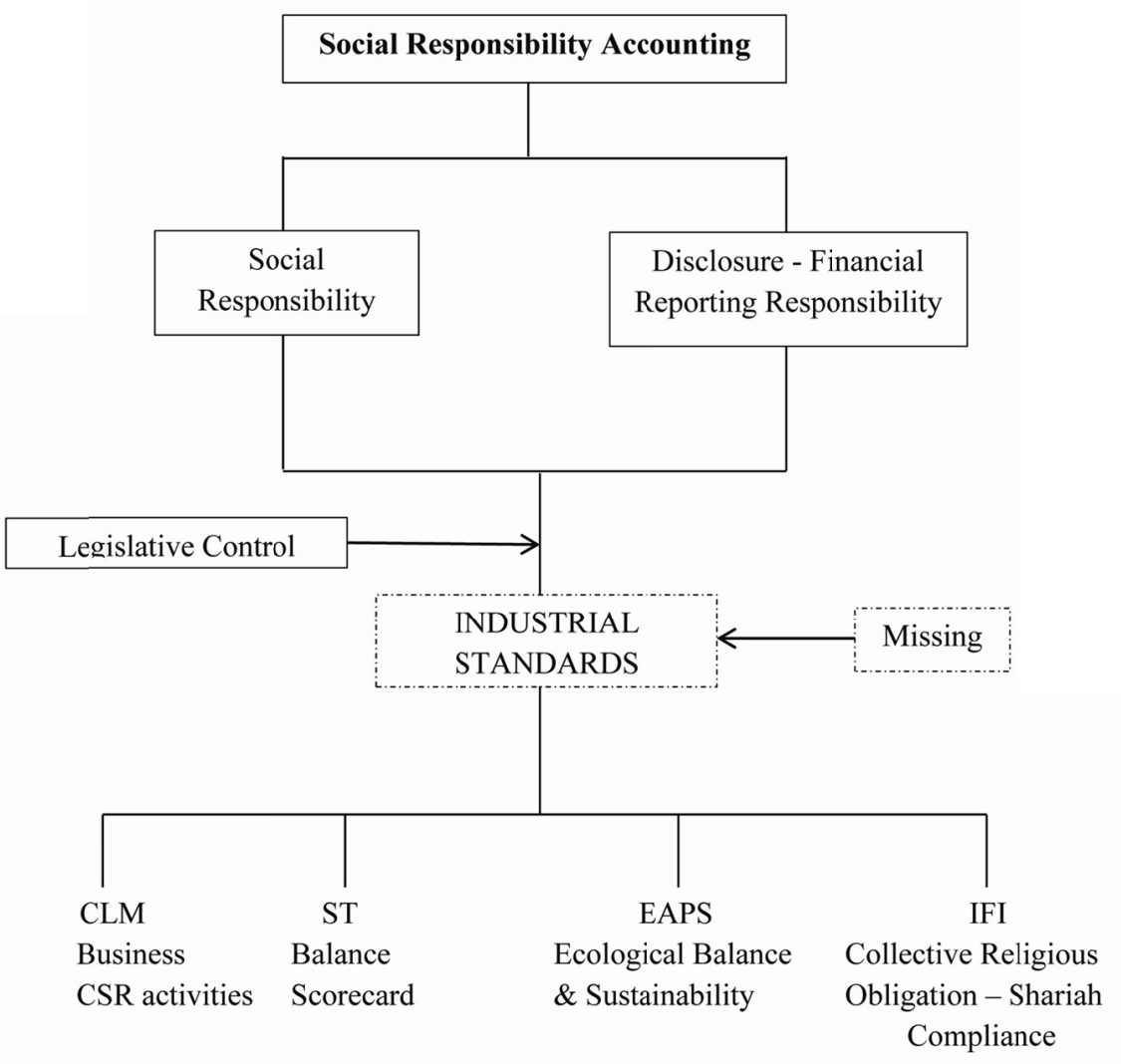

Figure 1. Showing the different approaches of social responsibility accounting and their focuses

Currently, a certain acceptable level of economic performance is needed before a firm's resources are allocated and its strategies prioritized to meet the social demands. Because of this, it is concluded that the best approach to Social Responsibility Accounting is currently based on a stakeholder theory of strategic management. What should be underlined in these findings, however, is that it needs to develop an intensive research on the financial case for CSR, particularly with establishing standards and quantifiable indicators to assiess the performance of the economic units.

It is also can be concluded that for each organization different diagnostic and interactive approaches are used through Social Responsibility Accounting (SRA) as SRA perceives a different sense of responsibility towards the 
society.

\section{Scope for Further Study}

The study as an inductive research concentrated on the philosophical aspects of the different approaches of SRA. However, the study can be empirically tested across the various industrial economic units in a geographical area and the same can be extended to industries as a whole. This will pave way to establish global industrial standards to govern, manage and control over social responsibility accounting.

\section{References}

Bamzahem, F. (2003). Effect of environmental accounting disclosure on the investment decisions of the public joint stock companies in Jordan. Unpublished MA thesis. Al Al Beit University, Mafraq, Jordan.

Baydoun, N., \& Willett, R. (1997). Islam Ethical Issues in the Presentation of Financial Information Accounting, Commerce and Finance. The Islamic Perspective Journal, 1(1).

Bowen, H. R. (1953). Social Responsibilities of the businessman. New York: Harper Publishers.

Brown, L. R. (2001). Eco-Economy, Building an Economy for the Earth. W.W. Norton \& Company, New York, NY, 2001.

Capron, M. (2006). A European Vision of the Differences between the USA and Continental Europe regarding CSR: Why CSR in Europe is a political object and not an ethical one. In C. Gendron \& J. Pasquero (Eds.), Advancing theory in CSR: an intercontinental dialogue (pp. 8-9). Montreal CSR International Workshop. Montréal: Université du Québec à Montréal.

Carroll, A. B. (1999). Corporate social responsibility evolution of a definitional construct. Business \& Society, 38(3), 268-295. http://dx.doi.org/10.1177/000765039903800303

Cornelia, D., Chirata, C., Camelia, I. L., Florian, C., \& Gina, R. G. (2010). The externalities in social environmental accounting. International Journal of Accounting and Information Management, 18(1), 1930. http://dx.doi.org/10.1108/18347641011023252

Crowther, D. (2000). Social and Environmental Accounting (p. 7). London: Financial Times Prentice Hall.

European Commission. (2001). Promoting a European Framework for Corporate Social Responsibility. EC Green Paper, Brussles. $\quad$ Retrieved from http://eur-lex.europa.eu/LexUriServ/site/en/com/2001/com2001_0366en01.pdf

Farook, S. (2007). On CSR of Islamic Financial Institutions. Islamic Economic Studies, 15(1). Retrieved from http://www.academia.edu/1220918/On_corporate_social_responsibility_of_Islamic_financialinstitutions

Harazin, P., \& Horváth, G. (2011). Relation between Environmental Accounting and Pillars of Sustainability.

Heath, R. L., \& Ni, L. (2008). Corporate Social Responsibility. Institute for Public Relations. Retrieved from http://www.instituteforpr.org/essential_knowledge/detail/corporate_social_responsibility

Hopwood, A. G. (2009). Accounting and the environment. Accounting, Organizations and Society, 34(1), 433439. http://dx.doi.org/10.1016/j.aos.2009.03.002

Jones, T., Wicks, A., \& Freeman, R. E. (2002). Stakeholder theory: The state of the art.

Kakabadse, N. K., Rozuel, C., \& Lee-Davies, L. (2005). Corporate social responsibility and stakeholder approach: a conceptual review. International Journal of Business Governance and Ethics, 1(4), $277-302$. http://dx.doi.org/10.1504/IJBGE.2005.006733

Maali, B. M., Casson, P., \& Napier, C. (2006). Social Reporting by Islamic banks. Abacus, 42(2), $266-289$. http://dx.doi.org/10.1111/j.1467-6281.2006.00200.x

Marcinkowska, M. (2007). Triple bottom-line reporting: a framework for banks. Paper presented at the European Accounting Association Congress. Retrieved from http://www.eaa2007lisbon.org/main.htm

Margolis, J. D., \& Walsh, J. P. (2001). People and profits: The search for a link between a company's social and financial performance. Psychology Press.

Mathews, M. R. (2007). Mega-accounting and reporting: a proposal for further development. Paper presented at the European Accounting Association Congress. Retrieved from http://www.eaa2007lisbon.org/main.htm

McElhaney, K. (2009). A strategic approach to corporate social responsibility. Leader to Leader, 52(1), 30-36. http://dx.doi.org/10.1002/lt1.327 
Mook, L., Quarter, J., \& Richmond, B. (2003). What counts: social accounting for nonprofits and cooperatives (pp. 11-35). London: Sigel Press.

Nadia, A., Cagtlin, N. A., Maria, M. G., \& Maria, L. S. (2011). The implications of Corporate Social Responsibility on the Accounting Profession: The Case of Romania. The Bucharest Academy of Economic Studies, $\operatorname{XIII(29),~221-234.~}$

Nkaiwatei, A. O. (2011). Relationship between Social Accounting Practices And Profitability: The case of oil industry in Kenya. A Research Project Submitted in partial Fulfillment of the Requirement of Master of Business Administration, School of Business Administration, University of Nairobi.

Ougaard, M., \& Nielsen, M. E. (2003). Corporate Values and Responsibility: The Case of Denmark. Copenhagen: Samfundslitteratu, Teaching CSR: Agendas and Inquiries.

Paul, C. J., \& Siegel, D. S. (2006). Corporate social responsibility and economic performance. Journal of Productivity Analysis, 26(3), 207-211. http://dx.doi.org/10.1007/s11123-006-0016-4

Rahahleh, M. Y., \& Sharairi, J. A. (2008). The Extent of Social Responsibility Accounting Application in the Qualified Industrial Zones in Jordan. International Management Review, 4(2), 6.

Steele, A. P., \& Powell, J. R. (2002). Environmental accounting: application for local authorities to quantify internal and external cost of alternative waste management strategies. Environmental Management Accounting Network Europe, Fifth Annual Conference, Gloucestershire Business School, 11/12 February.

Stephen, S. P. (2004). The Economics of Corporate Social Responsibility. Export wise, Winter.

Vinten, G. (2002). Public Sector Corporate Governance-The Turnbull report. Credit Control, 23(1), 27-30.

Waddoc, S. (2003/4). CSR-Highlights of the debate. EBF, (16),

\section{Copyrights}

Copyright for this article is retained by the author(s), with first publication rights granted to the journal.

This is an open-access article distributed under the terms and conditions of the Creative Commons Attribution license (http://creativecommons.org/licenses/by/3.0/). 